\title{
Biblical Mentorship as Discipleship to Enhance Adventist Students' Commitment to Faith: A Practical Model for Nurturing and Retention Strategies at the University of Arusha in Tanzania
}

Isacka Vitus Ndaruhekeye*

Adventist University of Africa

DOI:10.36348/sjhss.2021.v06i02.005

| Received: 02.02.2021 | Accepted: 17.02.2021 | Published: 26.02.2021

*Corresponding author: Isacka Vitus Ndaruhekeye

\section{Abstract}

Many Adventist students at the University of Arusha cease to participate in church programs like evangelism, nurturing one another, being interested in prayer meetings and other worship programs as soon as they join university studies. It is like in their previous levels of study they were not participating in these programs or they start to neglect them when they reach this level. The research that was done from 2017 to 2018 showed that six Adventist students were identified as being involved in sexual immorality and three in drug abuse, one in abortion while five students were found involving themselves in drinking alcohol. More than seventy percent of Adventist students were not participating in the church mission activities at the University of Arusha. Mentorship as a discipleship relationship between the mentor and mentee for the purpose of holistic growth seems to be more practical both in the Old and New Testament. This works as the means to minimize the problem. This article is dedicated to find out the biblical principles which were used in the Old Testament and in the New Testament to enhance the commitment of the Adventist students to faith in God. These principles will be useful in the plan of improving the Adventist students' commitment to faith at the University of Arusha. In the Old Testament, mentorship was used as the method to heighten and nurturing the believers to be committed to what they believed while the New Testament used the discipleship techniques to fulfill the same goals.

Keywords: Mentor/mentorship/ discipleship, commitment, faith, relation, church, mission.

Copyright (C) 2021 The Author(s): This is an open-access article distributed under the terms of the Creative Commons Attribution 4.0 International License (CC BY-NC 4.0) which permits unrestricted use, distribution, and reproduction in any medium for non-commercial use provided the original author and source are credited.

\section{INTRODUCTION}

The University of Arusha (UoA) is the only institution of higher learning that is owned by Seventhday Adventist Church in Tanzania. It is located in the Northern Tanzania Union Conference (NTUC) of the Seventh-day Adventist Church. Geographically the University is situated in Northern part of Tanzania in Arumeru district about 30 kilometers from Arusha city. The Head quarter of Arumeru district is known as Usa River town with a big market that sustains the need of the indigenous of this area. The university is near Mount Kilimanjaro, Mount Meru, Arusha National Park and Kilimanjaro International Airport.

Currently the University of Arusha is witnessing a drastic decrease of Students' enrolment by fifty percent compared to four years ago. Many students live in rented houses among the villages surrounding the institution while few live in university hostels.

The number of students' enrolled at the University of Arusha decreased from from over 3000 in the academic year $2013 / 2014$ to 1,124 in the academic year 2017/2018 [52]. In this year the analysis showed that the Adventist students were 343 while NonAdventist students were 781 which made the total number of 1,124 students [57]. The pastoral observation realized that the spiritual deterioration of Adventist students happened soon after they entered the university studies. Adventist students lost their interest in personal prayers and bible study and participation in spiritual activities, this contributed to the arousal of the interest in the study. 


\section{Statement of the problem}

Many Adventist students at the University of Arusha do not participate in church programs like evangelism and nurturing, attending mid-week prayer meetings and Friday vespers as soon as they join university studies. It is like they were not concerned or purposely they neglected to work on their spiritual growth and discipleship in general. The research that was done in the year 2017 to 2018 showed that six Adventist students were identified being involved in sexual immorality and three in drug abuse, one in abortion while five students were found involving themselves in drinking alcohol. Seventy percent of Adventist students were not participating in the church mission activities at the University of Arusha.

\section{Justification}

The research is justified to be significant because it is the fulfillment of the mission statement that Jesus gave to the church. It is the responsibility of the church to make disciples in all their activities on earth. This is a mandatory statement; it is the reason for the existence of the church on planet earth. The potency of the Seventh-day Adventist Church depends on committed students who believe in the mission of God (Matthew 28:19, 20). The targeted group of this dissertation is also unique and special. If the church wants to see it's university students not only remaining observers today, but also taking their place as the next generation of moral and responsible leaders then this research is timely. This can only happen if they have been made disciples of Jesus properly and appropriately taught to maintain it.

\section{Purpose for the Study}

The purpose of this research is to develop discipleship program for students' spiritual growth. It is the hope that the program will help the Adventist students at the University of Arusha and other institutions where Adventist students are studying to minimize the growth of immorality. The expected result of this research is to have converted Adventist students who will propel the development of the church and the nation at large.

\section{Delimitation}

Although this dissertation is intended to find out the workable ways to discipling Adventist students at the University of Arusha in specific way, it will also help other educational institutions which are located within Tanzania and abroad.

\section{Expectation}

It is expected that at the end of this research through the implementation of the program the church will produce Adventist students who will be stable in their faith and committed to Jesus their Lord and savior. Specifically the prospect is to see Adventist students at the University of Arusha and the church at large fostering spiritual growth by doing the following: a) A big number of Adventist students participating in church worship programs

b) Attending Sabbath afternoon bible study programs

c) Avoiding Complacency

d) Overcoming fornication and adultery

e) Many will be bible readers and prayer warriors

\section{LITERATURE REVIEW}

Mentoring in discipleship can be understood as relationship between the mentor and mentee for the purpose of wholistic growth. This process can be formal or informal depending on the plan of the people involved. Describing the word mentor the following Encyclopedia [1] states,

The term mentor describes a person who consciously and with purpose fosters a relationship between the target of such efforts, the protégé, and the mentor. Mentors typically are older or more seasoned and having a level of experience that allows them to provide guidance, support, and a frame of comparison for protégés to guide their behaviors, choices, thoughts, attitudes, and emotions.

There are several examples of mentoring in the Old Testament which can be used as discipleship models in the contemporary world. In most cases, the mentorship in the Old Testament seems to be based on two major factors; succession and legacy. Using these factors Langston [2] states that Moses meeting with his father-in-law Jethro produces the judicial system by which the Israelites will operate, and sets the stage for receiving the law code on Mt Sinai.

It is evident that Jethro provides judicial system in leadership as his legacy in mentorship. Also the mentoring relationship between Elijah and Elisha aims to get successor as Keil and Delitzsch [54] commentary state that according to what follows, all that Elijah accomplished immediately was to call Elisha to be his successor. Smyth and Helwys [3] exhort either way; Elisha is recruited as the follower and successor of Elijah. Moses mentors Joshua and Caleb; Elisha mentors the sons of the prophets and Naomi mentors Ruth for the same purposes. Generally, mentors desired to leave legacy and to have successors to replace them after they retire.

\section{Jethro Mentors Moses}

The relationship between Jethro and Moses seems to be a divine appointment. Jethro being Moses' father-in-law; a senior-level person with personal interest in Moses, his son-in-law, he appears to be interested in Moses because his daughter is married to him; possibly his wish is to see the entire nation of Israel progressing (Exodus 18:1). Commenting on the reasons for Jethro to come to see Moses Wesley comments, Jethro to congratulate the happiness of Israel, and particularly the honor of Moses his son-in- 
law; comes to rejoice with them, as one that had a true respect both for them and for their God. Influenced by love, Jethro seems to be concerned with the holistic life of Moses (Exodus 18:17-24)[58].

Jethro is a God fearing person for in his statements he never excludes God. Of everything he advises, he wants it approved by God before it is practiced (Exodus 18:19). A mentorship Relationship like this is needed because mentors are not infallible neither are they all-knowing. Jethro admits that whatever he advises is to be approved by God. This is probably because he does not want to take the credit and honor once Moses succeeds upon applying those principles (Exodus 18:23). The father-in law seems to know that Moses has a better Counselor than he, and to His counsel he referred him. On this, Wesley comments, Jethro knew that Moses had a better counselor than he was, and to his counsel he refers him. It is advised that, mentors should not impose things to their mentees. Rather they discuss and allow God to approve them for His glory.

\section{Moses Mentors Caleb and Joshua}

Moses is described as a leader with the spirit of humility (Hebrews 3:1-5; Numbers 12:3). As the leader of the Israelites, it is needful to mold young people into leadership. It seems that he sees some potential in Caleb. Again, consider the two major factors for mentorship. Being convinced with Caleb's trust in God and readiness to serve Him, he sends him with the other eleven spies (Numbers 13:3, 6). Yet again, God is involved in appointing them. It appears that, this shows how important it is to involve God in mentorship as a discipleship relationship in the Old Testament. The Scripture confirms why he is elected to be among the twelve spies. Scholars have written about Caleb as a man of God whose life testified his real trust in God. He was known for his commitment to Jehovah God. He is remembered for his faith and trust in God. Probably his character contributed much to his power and diligent report to Moses and the entire community of God about the land and the people there in. Trusting in God prepares people for greater and powerful opportunities to serve. Concerning Caleb Wheadon [59] commentary states, Caleb - the spy from the tribe of Judah here begins the minority report, which is characterized by an unwavering trust in Jehovah. He has a strong faith in God, mentorship as discipleship prepares trustworthy leaders. Moses seems to prepare Caleb as a leader for the future.

The same factors which convinced Moses to include Caleb among the spies leads him to include Joshua whose first name was Hoshea meaning save us oh God (Numbers 13:8, 16). His name was changed to Joshua signifying the role he was going to fulfill. He is given the name which glorifies God who conquers and saves his people as Trapp's [56] commentary exhorts, His name was now changed from save us oh God, to
God shall save us. Joshua is the type of Christ in his work. He is under- making to be Moses' successor after his death (Joshua 1:1, 2). It looks like God is fully involved intimately in the successful mentorship experience in the Old Testament (Joshua 1:5). On this understanding Pitkanen [4] exhorts, Joshua's leadership and authority will be legitimated by Yahweh's presence (vv. 9, 17).

The Old Testament mentor/mentee relationship as discipleship is not purposeless. Dozeman [5] describes two main goals of mentor/mentee relationship as to be aware of the unconditional obligation of God to past promises and the conditional promise of triumph based on the observation of the Law. Also, making God's people enjoy the promises of God eventually (Joshua 1:6). The relationship between Moses and Joshua in the Bible shows how

God prepares young leaders through experienced leaders (Numbers 27:18). "Iron sharpens iron, so one man sharpens another" (Proverbs 27:17).

The Bible shows a close relationship between Moses and Joshua for the purposes of discipleship making. Joshua was younger than Moses; he was supposed to learn many things under his feet and gain more experience from him. Note also their relationship was friendship-based rather than the hierarchal relationship. Their age difference did not create a superiority and/or inferiority complex. The target was to prepare leaders to join the work with gained experience from current active leaders. This style of leadership was to some extent successful because it was practical and intentional.

\section{Jonathan Mentors David}

Mentorship operates as the desire to fully defend someone. Chisholm [6] states, Jonathan fully supports David, while Saul tries to murder him. Jonathan and David seem to have a unique relationship; a relationship to death. In that, it is stronger than death for the fact that he endangers his life for his friend, David (1Samuel 20:32,33). This may demonstrate that mentor/mentee relationships sometimes may cost the life of the mentor. In this case, Jonathan is the mentor while David is the mentee. Their relationship is strengthened by the covenant which is done under the witness of God (1 Samuel 20:12-16). This seems to be a serious business due to the reason that God was involved fully. The covenant seems to engage all; each one fulfills the role, Jonathan does the talking while David implements the stated agreement before the Lord. Bodner [7] comments, Jonathan does all the talking, and David goes along with the stated transaction: 'And the two of them cut a covenant before the LORD'. It appears that, the relationship in mentoring as discipleship should be done in the presence of God as the witness. 
The authenticity of their covenant was shown after the death of Jonathan. David respects and keeps the oath by preserving the life of Mephibosheth, the son of Jonathan (2 Samuel 21:7). Again Jonathan is interested in David because he is approved by God to be the next king. And according to the leadership style at the time, the king's elder son was expected to be the next king. Jonathan, the elder son of King Saul, is not interested in political mediocre. Instead, he observed and listened to God's instruction.

True mentors are led by love and care for others rather than greed and selfishness. Commenting on love Heaster [8] states, the love of David for Jonathan is apparent. Jonathan's love for David is sacrificial in nature as Bodner [7] comments again, It would appear that Jonathan's love for David is sacrificial, and there are real emotional currents that connect the two friends. This is in harmony with the Ten Commandments as instructed by Jesus in Matthew 22:39 to "love God and your neighbor with all your heart"

\section{Elijah Mentors Elisha}

Another example is the relationship between Elijah and Elisha (1 Kings 19:19-21). Elisha is called from his normal activities to join God's work. This needs commitment as a true response to the call. Elijah found Elisha at work; he abandons the job he was doing for the sake of God's work. Probably, this demonstrates that God calls people who are busy; not people who are idle. Concerning Elisha's commitment to the call, Smyth and Helwys [3] comment, what counts is that he left his oxen and followed. Elijah does not pick anyone to succeed him. By the guidance of God, he picks the committed one who leaves everything for the sake of the mission of God. Preparing effective young people for ministry needs God's guidance of what should be done.

It needs total commitment to occupy Elijah's position as demonstrated in Elisha's performance. It is not an easy decision for Elisha to make; slaughtering his oxen which enable him earns his income. Yet, he sacrifices everything he depends on. Again, the call to discipleship comes with some kind of test perhaps aiming to strengthen his commitment (2 Kings 2:2, 4, $6)$. He is encouraged by Elijah to remain at one station while his mentor goes to the next station of the schools of the prophets. He never allows his master to go alone; thus shows his serious commitment.

The mentorship relationship between Elisha and Elijah is initiated by God (1 Kings 19:16). Elijah accepts the instructions of God for Elisha without hesitation. Later, he confirms it by throwing the cloak around Elisha (1Kings 19:19; 2 Kings 2:13). These verses show the plan of God to start the relationship between Elijah as the mentor and Elisha as the mentee. From the common sense, Elijah drops the cloak on
Elisha to symbolize the call to ministry succession. This may be the reason why after the ascension of Elijah, Elisha continues with Elijah's work including ministering to sons of the Prophets (2 Kings 2:15). Sometimes the call to ministry may come unexpectedly according to Smyth \& Helwys [3].

It is not clear why the narrative presents the "call of Elisha" as it does. The call itself is nonverbal (19:19). There is only a dramatic act that both parties understand. Elisha understood it as a summons to "follow" (19:20); in the end he does "follow" and becomes Elijah's aide (19:21).

Also in the Old Testament, it seems that the mentor/mentee relationship is characterized by persistence and commitment of the mentee. The mentee is tested on his/her commitment levels in the work he/she is going to join. This may create a healthy tension between the mentor and mentee. Knowing that he about to ascend to heaven, Elijah insists Elisha to remain while he goes to Bethel, Jericho and Jordan (2 Kings 2: 1, 2, 4, 6). From this example, the mentorship relationship needs humility and persistence. All those examples of mentorship relationships in the Old Testament work as what is called discipleship in the New Testament.

\section{Elisha Mentors the Sons of the Prophets}

To have a God-fearing generation does not come by chance. A God-fearing generation is prepared. Elisha seems to be the only prophet who related closely to a group of people. Hobbs [9] affirms, the only prophet directly associated with the group is Elisha. The association he talks about seems to be like the relationship between mentor/mentee (2 Kings 2:18-25); that is why he can be described as preparing a generation of God-fearers. Any organization and institution which does not invest in young people soon or later will cease to exist. Elisha works closely with the sons of the prophets, he seems to be concerned with their needs whatever situation he finds them in, he is interested in solving it in any way possible (2Kings 4:38-41).

Responding to the needs of people must be the priority of the ministers of the gospel. Elisha touches the needs of people through miracles which is done with heartilily compassion According to Hobbs [9]. In the case of Elisha in chap. 4, the motivation is the desire to respond to pressing human needs. The motivation is compassion. In preparing God-fearing young generation the mentor/master must be sympathetic. This compassionate spirit allows both sharing the challenges and finding ways to solve those (2 Kings 6:1, 2, 4-7). It is not enough to empathize but is better to move from stating a problem to the final resolution of the problem. This shows that the true relationship in discipleship must find ways to solve various problems. Prepared 
God-fearing young generation will always want to be with their trainer/master wherever they are $(2$ Kings $6: 3$ ). A close relationship between mentors and mentees helps each one to experience holistic healing.

\section{Naomi Mentors Ruth}

The Bible shows the importance of the roles of experienced women with young women. Young women need explanation about life in marriage and the way they can take care of their husbands as well as their children. The experienced women seem to know the techniques on how to attract men in an acceptable manner (Ruth 3:3-5). Naomi plays a significant role in mentoring Ruth. Naomi represents the ethical women who are ready to stabilize young women's marriage.

Regardless of her bitterness and agony she advised a better direction for her daughters-in- law as Sakenfeld commentary states, Naomi, despite her sense of hopelessness at the loss of her husband and sons, offered a plan for the security and happiness of her daughters-in-law (1:89). Naomi's concern for her daughter's comfort in life is recommendable to every mentor and disciple maker. The principle of discipleship functions here properly. Although Ruth seems to benefit much from Naomi's mentoring skills; in reality Naomi also benefited from Ruth as again Sakenfeld commentary exhorts for Naomi, Ruth's presence is as much a reminder of tragedy as it is a potential comfort.

Again the two factors seem to be evident in this mentorship relationship: Naomi knows that these young women need husbands, so she has the enthusiasm to see them succeeding in their life long journey (Ruth 1:8, 9). Since the relationship between mentor and mentee aims to grow each other, Ruth seems to love her mother-in-law at whatever cost (Ruth $1: 16$, 17). And also, God is involved in their conversation. Ruth seems to be converted to Naomi's God as Sakenfeld again comments, Thus Ruth's determination to accompany Naomi on the journey from Moab to Bethlehem, to cast her lot with an older woman rather than to seek her own welfare in her homeland, goes beyond normal expectations of their relationship. Ruth's choice to follow her mother- inlaw seems to advocate Agape love (Ruth 1:16, 17)[55].

\section{Mentorship as Discipleship in the New Testament Christ Mentors the Twelve Disciples}

Since mentoring is mainly about the relationship between mentor and mentee, the New Testament period needed this to foster the spreading of the gospel. Jesus mentored the twelve disciples. The model of Jesus teaches that sometimes mentoring as disciple-making needs time to share ideas and answer questions of the learners (Matthew 24:1-4). According to Gaebelein [10] all the followers of Jesus should participate in making disciples of Jesus by teaching the nations (Matthew 28:18, 19). This can be as the same as mentoring in the contemporary society. Christ's disciple-making in the New Testament works as mentorship, and it is practical and live. Sometimes He could take them aside after busy days and have a rest for a while. He really cared for them. This kind of relationship creates an unshakable friendship which makes disciples to love their master to the extent that whatever he asks them to do, they do it joyfully. Jesus seems to teach His disciples about their responsibility in the parable about His coming Kingdom. Matthew 25 teaches practical, accountable and responsible discipleship. The parable of the ten virgins, the parable of the talents and the judgment of the people are according to their deeds. This calls for a responsible disciple. Jesus mentorship style was engaging; allowing disciples to relate with Him closely. A disciple is a service render. Mentoring as discipleship needs both sides to participate; the participation of mentor/mentee in mentorship welcomes success. This should be supported and emphasized as Maxwell [11] states, encourage two-way participation with the people you influence. Intentional mentorship participation calls for commitment of both the mentor and mentee. Whether formal mentorship or informal mentorship both need true commitment from the participants because each one of them is responsible to do his/her part.

\section{The Great Commission as Mentorship Model in the New Testament}

Matthew 28:19-20 starts with the word, 'all authority' on earth and in heaven signifies Jesus' power which is not only on earth but also in heaven. The authority of Jesus in mission is on the battlefield; it sends His followers to go to every place where people may be found. It should be clear that the work of making disciples and mentees is impossible if it is left in human hands alone. For the work to be effective, God must fully be in charge Hagner [12] comments, theirs is indeed an awesome responsibility: to go make disciples of all nations, baptize and teach. If left to . . . devices and strength, the task would be overwhelming.

The second 'all' intonates that the mission of God is directed to all people from all nations. This is emphasized within the Great Commission to show the Church the inclusiveness of the message as Keck [13] expounds, after the resurrection; the invitation to disciples is open to all people of all nations. The authority enables the disciples of Jesus to make all nations to be the disciples of Jesus. This does not mean they force them to believe; instead they confront any resistance with the power of Jesus.

"Nation" does not mean countries or nationstates. The Greek language for nations can mean ethnic/racial or tribal groups. This does not exclude any person in the plan of redemption. Rather, all people of all classes are candidates of the kingdom of God. According to Matthew [14] Christ is the sole universal Monarch; he is Lord of all, Acts x. 36... All souls are 
his, and to him every heart and knee must bow, and every tongue confesses him to be the Lord. The general understanding of "all" lies on recognizing Jesus as the Lord of all peoples. This should be comprehended through creation and the redemption plan (Genesis 1:26, Isaiah 2:2; 25:6; 56:7; John 1:3). Preaching to all nations is a universal mandate as Gaebelein [10] states, proclaiming the gospel of the kingdom to all nations (24:14) takes place in obedience to a universal mandate (28:18-20).This tells that preaching the great commission is the Universal command which is for all who have accepted Jesus Christ to be their personal savior.

"All that I commanded" is the third phrase which refers to the teachings which Jesus expects His followers to teach (Matthew.28:18). Keck [13] comments that 'all' here reflects the all of Matthew26:1 and it refers not only to the Sermon on the Mount but to all of Jesus' teachings contained in the Gospel as well, especially the five great discourses. The Bible must be the textbook of teaching and instruction rather than mere human logic and philosophy.

Sometimes, the followers of Christ are tempted to teach from their own syllabuses while neglecting the real Truth they are supposed to teach. What did Jesus teach? He taught the whole Bible from the Old Testament to the New Testament (Luke 24:27). The whole Bible qualifies to be the teachings of Jesus because it is inspired by the Holy Spirit (2 Timothy 3:16. Concerning the teachings of Jesus Gaebelein [10] has this to say.

It then follows that by carefully passing on everything Jesus taught, the first disciples themselves eyewitnesses--call into being new generations of "earwitnesses" (O'Brien, pp. 264f.). these in turn pass on the truth they received. So a means is provided for successive generations to remain in contact with Jesus' teachings (cf. 2 Tim 2:2).

Teaching all He commanded goes beyond His verbal teachings in the Gospels. It includes His entire life in history from the beginning of his ministry to the end. This includes what the disciples saw Him do. Although evangelism is important for the life of the Church members, it is not God's ultimate goal for human beings but His goal is to make them disciples of Jesus. The disciples of Jesus should know that their task is mainly to make others to be disciples of Jesus as either way it is binding on all Jesus' disciples to make others what they themselves are-disciples of Jesus Christ. This does not invalidate the importance of evangelizing and converting as many people as possible. Hagner [12] comments that the emphasis in the commission thus follows not on the initial proclamation of the gospel but more on the arduous task of nurturing into the experience of discipleship.

Making disciples promotes evangelism; that means members of the Church become more active. People need to know God first before they serve Him in any capacity. Passion for God increases in the members when they are converted before they go in the field to serve. It is not in evangelism where believers grow but in disciple-making. Evangelism brings people into the churches while disciple-making pays more attention to their wholistic growth.

How can people go to evangelize while they are not sure of the sender? Before they go out for evangelism, true Christians learn to be like Jesus first. Self-denial is one of the elements of disciple-making. It is also the central key of successful Christianity. A disciple of Jesus is expected to count the cost of discipleship before he continues. Hence the reason why numbers do not matter in spiritual matters sometimes. God wants genuine Christians who are really serious in their spiritual affairs.

The goal of making mentees or disciples is salvation. God has had a plan to save humanity since the foundation of the world. Thus, before disciples do outreach for the mission, they should start with inreach. The believer who has a purified heart and joy that surpasses human understanding is learning to be the disciple of Jesus. Once he reaches this level he will be ready to carry the message to others (Matthew 5:13, 14). This is because the work of disciple-making is not a manmade task, it originated from God.

If the love for and the relationship with God of believers shall be weak, it may be difficult

for them to love and relate with their fellow human beings (Matthew. 6:33). This may lead to failure in evangelism. This is because compassionate spirit is needed for the mission and this can only be attained through a genuine relationship with God. Prioritizing the kingdom of God in their lives will lead them into successful evangelism (Luke 22:32). This does not mean to ignore other life affairs as Gaebelein [10] exhorts that instead, they are to replace such pursuits with goals of far greater significance. Thus, there should be a balance between evangelism and making people disciples of Jesus. The Church is called not only to evangelize people but also to make them true disciples of Jesus.

True discipleship is genuine and honest; it is never a life of pretension. For it to be effective both the disciple maker and the disciple must learn from Jesus how to relate with each other. In the context of the New Testament, the disciple was under an experienced master learning to be like him. The purpose of this kind of training is to prepare a generation of moral people. This was done in religious perspective as well as social 
and political affairs. According to Anderson [15] discipleship is the process of building into one another the life of Christ. The followers of Christ are supposed to be committed to the work of making others disciples of Jesus as He commanded. This work is what makes the church exist, so it should be the priority of the church to make disciples of Jesus. This is the major activity which Jesus left to His followers and He does it Himself using them as weak vessels.

\section{Barnabas Mentors Paul and John Mark}

The early church was filled with strong nurturing system; the apostles practiced mentoring as disciple-making in a companion and teamwork style. The experienced apostle could share difficulties and joys in ministry with those inexperienced to help them learn things. For example, Barnabas is known in the New Testament as the gifted man of God who mentors abandoned people in ministry. When Saul of Tarsus was not fully accepted by the Church as a convert, he patiently mentored him and encouraged the Church to accept him (Acts 11:25, 26). This is stated by Gaebelein [10], it was Barnabas, and Luke says, who was willing to risk accepting Saul as a genuine believer and who built a bridge of trust between him and the Jerusalem apostles. It seems that Barnabas was gifted to encourage the people to press on in life no matter what situation one is going through.

The work of Barnabas and Paul toward John Mark was practical, because he was their attendant. He also learnt from them through what he saw them doing. According to Gabelein [10] the following is said, thus Barnabas and Saul began their mission in the synagogues of the city, and John Mark was with them as their helper (hyperetes). This was after the conflict and misunderstanding between Barnabas and Paul. While Paul was a mission-oriented apostle, Barnabas was a people's success-oriented apostle. Refusing John Mark to be in the team for one mistake, Paul was not a good example in mentoring as disciple making though later on he restored the relationship with John Mark as Barret states, "See further Colossians 4.1 0; Philemon 24; 2 Timothy. 4.11. According to Barret [16] if these verses, or any of them, were written by Paul himself (and perhaps even if not) we must conclude that John Mark was forgiven and restored to service with Paul. However, Barnabas was more concerned with mentoring a young generation in spite of their weaknesses. Paul was more anxious about evangelism, than encouraging or mentoring those who seem not to be committed to mission.

\section{Paul Mentors Timothy}

Paul mentored Timothy, a young man willing to join ministry and become a disciple of Jesus. He closely advised him to be strong and exemplary in faith and on Christian ethics (1 Timothy.4:12). Paul did all what was needed for Timothy to be accepted by both Jews and Greek Christians. He was moved by the energetic young man who would build the kingdom of God. According to White [17] in Timothy, Paul saw one who appreciated the sacredness of the work of a minister; who was not appalled at the prospect of suffering and persecution; and Who was willing to be taught?

To Paul, Timothy was like his son as far as his relationship with him was concerned (1 Timothy 1:2; Acts 16:1-5). Knowing that Timothy was a humble young man, Paul insisted on boldness and a life of cleanliness (2 Timothy 2:15, 22, 25). Paul shares necessary teachings for ministry so that Timothy would-be useful in ministry. Paul spent time in shaping Timothy in ministry because he knew that he was a vessel of God invested with God's gifts to reach many with the gospel (1 Timothy 4:1-5).

\section{Experienced Women Mentor Young Women}

In the New Testament mentors do their work depending on their experience and age (Titus 2:3-5). Young women are privileged to get relational counsels and life conduct from old godly women. Commenting on this Fee [18] states, here the concern is chiefly about character and conduct in general; only the instructions for the younger women and slaves is relational... In this particular passage, old women are encouraged to teach young ones how to handle their homes by their conduct. The kind of mentoring which can be extracted here is the teaching through example as Platt, Akin and Merida [19] explains, older women were to "encourage," "admonish" (NKJV), or "train" (ESV), to counsel and advise the younger women "to love their husbands.

In this text young women seem to be potential for the stability of the family, they need orientation of how to care for their husbands and their children. Mentoring of this kind prepares these young women to be good disciples in their homes, churches and the society at large. As the younger women become disciples, they may produce other disciples including their spouses and children. However, discipleship is not limited to women alone as Platt, Akin and Merida [19] comment, older men need to disciple younger men, and older women need to disciple younger women. The power of the gospel should produce godliness in the life of all believers regardless of their gender. Therefore, either young men or young women all are equally in need of close nurturing attention in order for them to be mature spiritually.

\section{Elizabeth Mentors Mary (The mother of Jesus)}

The simple definition of mentorship is relationship; in these verses mentorship is clearly displayed. Mary visited Elizabeth not only because of their relative relationship but also because of their connection with God. Although Elizabeth was the cousin to Mary, that was not the only reason for their relationship. Their relationship was strengthened by God himself through his messenger who confirmed the 
miraculously conception of Elizabeth to her (Luke $1: 36)$.

The deliberate visit of Mary to Elizabeth the long journey of about fifty to seventy miles from Nazareth to Zachariah's home was not in vain, Gaebelein [10]. It was propelled by the burning heart for good tidings she was expecting (Luke 1:39).Luke uses the blessing Elizabeth gave Mary to call attention to Mary's faith, Gaebelein [10]. In this situation Mary needed a mentor who is mature and who has the same experience of conceiving, not only conceiving but marvelously conception.

The words of Elizabeth to Mary her cousin and Mary to Elizabeth signify the trust both had in God (Luke 1:44, 45, 46, 47). Mary stayed with Elizabeth for not less than three months, enough length for formal mentorship program to be effected. This is confirmed by Raymond as he says, '... Mary the mother of the Lord remained with Elizabeth about three months (1: 56), Brown [20] Staying with her for three months helped her to learn from the experience of each other. This is what should be done by experienced women to the growing up young women to prepare them to be dependable mothers in their families.

\section{Lois Mentors Eunice (The mother to Timothy)}

Another notable New Testament example of women mentorship apart from Elizabeth and Mary is the relationship of Lois and Eunice. The Bible describes the good conduct of Timothy as the result of careful mentoring activity which was done by Timothy's grand- mother towards his mother Eunice (2Timothy 1:5). These women are known because of their impact to those around them, Timothy is reminded not to forget his roots; these roots go way back, and his own faith is like that of his mother and grandmother.

It seems that Eunice, the mother of Timothy did a tremendous job to mold Timothy that is why Paul is convinced to believe that for sure a work was done. It appears that Paul knew Lois and Eunice the mother of Timothy personally, because he (with Barnabas) led them to faith in Christ during his first missionary journey (see Acts13:13-14:21). This tells how families may be the source of mentorship if parents may do their responsibilities to their children. Mentorship relationship is not a hidden program; note that people watch and they can tell if it is genuine or hopeless as David, Daniel and Tony [19] say, "What we do know is that these godly ladies' faith was observable to Paul."

Mentorship program can be done in the family level by biological parents; this is clear in the life of Lois to Eunice and Eunice to Timothy. Timothy not only had the privilege of a mentor, but he also had the gift of a godly mother (Eunice) and grandmother (Lois). This is what shaped his life and qualified him to be a useful vessel in the ministry.

\section{RESEARCH METHODOLOGY}

In the dictionary [21], methodology can be defined as, "The process used to collect information and data for the purpose of making business decisions. The methodology may include publication research, interviews, surveys and other research techniques, and could include both present and historical information. The methodology depends on what the researcher wants to include in his/her research though the elements that are mentioned above must be consisted. In this study of program development, the researcher shall use qualitative methodology.

The researcher preferred qualitative method because it focuses on understanding views and perceptions of people on the matter, which was the researcher's target. It aims to discover new thoughts and individual views through observing the gestures, postures and body languages of the people interrogated. Therefore it becomes easy to identify problems and providing solutions. Ndukwu [22] defines qualitative research as gathering non-numerical data that helps you understand the deeper meaning behind a topic.

\section{RESEARCH DESIGN}

The interpretive research design was used in the study. It dealt with the following questions, why is this going on? Why is this incident taking place? What sort of theories might help to understand and explain what is going on? Saldaña [23] asserts that writing interpretively aims for higher or deeper levels of thought — the "big ideas" about the nature of what's been investigated.

\section{Data Collection Procedure}

The first thing the researcher did was to give the official letter from the Adventist University of Africa where he is taking his studies to the University of Arusha Deputy Vice Chancellor Academics where the research is done. It was done so to fulfill the research ethics and to ensure collaboration in the process of data collection and intervention strategies. And also there were commitment form for respondents to secure both the researcher and the respondents in case of anything in the process of data collection. Rueda and Arnab [24], in their Handbook of Statistics state, this technique enables the researchers to obtain sensitive information while guaranteeing privacy to respondents.

The researcher used focus group interview discussion and one to one interview and interview guide method to get the answers for the above questions. Two focus groups were formed, one group aimed to consist fourteen students with equal gender ratio, and nine students turned up. This analysis of the nine students who attended was as follows; seven were males and only two females responded to the invitation. This group comprised almost representatives from each level of study that means from certificate level to degree 
level. The work began by prayer and then the researcher clarified their duty and gave them consent forms for each one of them to fill before they responded to the five research questions.

Another focus group included church members; to this the researcher used interview guide method to get their ideas. The researcher got twelve groups and they discussed and responded to the questions in a written form accordingly. This group was a mixed group because it included students, workers and even the indigenous of the surrounding areas of the institution. Members were identifies using the alphabet, group A to group L considering their gender. The following are three samples of tables showing how the respondents were identified accordingly.

\section{Respondents' naming samples}

Table-1:1 Sample of Respondent Identification

\begin{tabular}{|l|l|l|l|l|l|l|}
\hline S/N & FOCUS & GROUP & RESPONDENT & NUMBER & SEX & NAME \\
\hline 1 & F & G & R & $\mathbf{1}$ & M & FGR1M \\
\hline 2 & F & G & R & $\mathbf{2}$ & M & FGR2M \\
\hline 3 & F & G & R & $\mathbf{3}$ & M & FGR3M \\
\hline 4 & F & G & R & $\mathbf{4}$ & F & FGR4F \\
\hline
\end{tabular}

Table-1:2 Sample of Respondent Identification. (Interview Guide)

\begin{tabular}{|l|l|l|l|l|l|l|}
\hline S/N & GROUP & ALPHABET & RESPONDENT & NUMBER & FEMALE/MALE & NAME \\
\hline 1 & G & A & R & 1 & F & GAR1F \\
\hline 2 & G & B & R & 3 & M & GBR2M \\
\hline 3 & G & C & R & 5 & F & GCR5F \\
\hline 4 & G & D & R & 2 & F & GDR2F \\
\hline 5 & G & L & R & 7 & M & GLR7M \\
\hline
\end{tabular}

Table-1:3 Sample of Respondent Identification. (One to one Interview)

\begin{tabular}{|l|l|l|l|l|l|l|}
\hline S/N & HOSTEL & GIRLS & INTERVIEW & RESPONDENT & NUMBER & NAME \\
\hline 1 & H & G & I & R & 1 & HGIR1 \\
\hline 2 & H & G & I & R & 2 & HGIR2 \\
\hline 3 & H & G & I & R & 3 & HGIR3 \\
\hline 4 & H & G & I & R & 4 & HGIR4 \\
\hline
\end{tabular}

\section{Data Compilation}

Spirituality was the first theme which emerged as the response to the first research question which asked, "How can you describe Adventist students at the University of Arusha as far as spiritual life is concerned? The aim of this theme was to describe the spirituality of the Adventist students at the University of Arusha. And from this themes the following three subthemes emerged, complacency, misused freedom and pretension.

The second theme was 'committed faith' which emerged as the result of the second question which asked, "In your opinion, why are some Adventist students at the University of Arusha becoming active spiritually?" The goal of the second question was to know the sources of their commitment in faith. As the response to this theme, six subthemes arose; tests and challenges, priority, upbringing, involvement, attending prayers and participation.

The third theme namely, 'inactive spirituality' came in as the response to the third research question which asked, "In your opinion, why are some Adventist students at the University of Arusha becoming inactive spiritually?" the aim of the third question was to find out the reasons for the inactive state Adventist students have. Out of this theme three subthemes were developed, worldly influence, University leadership weakness and lack of involvement.

"Types of misconduct" was the fourth theme which came as the result of the fourth question which asked, "In what types of misconduct or immorality are Adventist students at the University of Arusha involved in or accused of being involved in?" This question was the key of the study, because its aim was to find out the distorting moral behavior amongst the Adventist students. It produced five subthemes which stand as types misconducts Adventist students at the University of Arusha are involved in. Fornication/adultery, stealing, alcoholism, inappropriate dressing and attending night clubs are the mentioned subthemes from the fourth question.

The fifth theme was 'strategies' this theme emerged as the response to the last question which asked, "What can the university of Arusha church and the University at large do to enhance student's commitment to faith?" In reality, this question was the core of the study, this is because its aim was to find out ways to eradicate and or minimize the situation which 
of course is the aim of any research. Six subthemes were recommended to combat the moral erosion which was discovered, reading the word, enforcing spiritual standards, being example, involving students, conducting seminars and making follow up in all things.

\section{THE RESEARCH FINDINGS DISCUSSION \\ 1. Spirituality}

As it was noted in table $1: 4$, there were five themes and several subthemes for each theme. Beginning with the first theme 'spirituality' almost all respondents regardless of gender and year of study came to the agreement that the spiritual situation of the Adventist students at the University of Arusha is not good. HGIR1 said, "The spiritual situation of Adventist students in this University is not good, most of them do not have a desire for spiritual things in their hearts." Generally the researcher wanted to know the opinions of Adventist students and church members concerning the spiritual situation at the University of Arusha. FGR4F exhorted, "The spiritual situation at the University of Arusha is not good. The hostels are not safe for students; there are Adventists who go to Disco and night clubs."

These behaviors are the indicators of the spiritual weaknesses of the Adventist students. Another respondent FGR7M saw both University and church leadership to be the reason for low spirituality of Adventist students as he stated, "The spiritual situation is not good. The University and the church is not seriously nurturing students." Melissa [25] concurs with the ideas of many respondents above as she affirms; the private school system is "morally rotten. According to the above quote it implies the situation in all private institutions whether secular or religious. This theme had three subthemes namely complacency, misused freedom and pretension. In this section these subthemes are going to be discussed chronologically below.

\section{a. Complacency}

The subtheme namely, complacency was the very first subtheme which emerged. A good number of respondents agreed that complacency is affecting Adventist students at the University of Arusha, this distorts their desire and zeal for spiritual matters, and they seem not to value spiritual things accordingly, this was from both students and church members' opinions. According to the observation of the researcher most of the words repeatedly used to describe the situation were like familiarity and no desire and enthusiasm for spiritual life as respondent HGIR3 stated, "It is true that many Adventist students in public Universities seem to be active in their spiritual life because they value the opportunity to worship God there. Most of them here become low spiritually because of familiarity." On the same GER1F said, "The spiritual status for Adventist students at UoA is not good because of familiarity." And on the other side FGR2M exhorted, "According to my observation I have done, I see that the spiritual enthusiasm/desire of the Adventist students at the University of Arusha is low compared to other public Universities."

All the above findings are in agreement with the opinions of [26] No matter how great the gift from God is, the power on the person is always destroyed by familiarity. For essence, familiarity is dangerous for spiritual life, this should be clear. Concerning how bad complacency is for spiritual life Bill and Mark [27] assert, with a mission of this magnitude, we all need to guard against complacency. This tells that complacency is not good at all for spiritual life stability because it destroys the spirit of growth in an individual.

\section{b. Misused Freedom}

The next subtheme was 'misused freedom' this seems to be one of the major and the reason for their spiritual deterioration. The overall finding shows that all the three categories of respondents the researcher met, agreed that Adventist students have more freedom, but they tend to misuse it when they join University studies and this is the source of immorality for many of them. This is similar to what HGIR3 said, "The spiritual status for Adventist students at UOA is not good due to the reason that many Adventists students have freedom without boundary while at the University." The age and freedom does not help them instead they destroy their life as the respondent goes on by saying; "Youth age and freedom without boundary distort them." With a loud voice this says a lot about the negative impact of freedom to Adventist students who join Universities. Expressing about the same situation for hostellers GBR4M stated, "It is worse in hostels, because students are free to go anywhere and do whatever they wish." No one cares because they are considered as mature people. Explaining about the same situation Taylor [28] says that freedom should not be to the expense of safety. In real sense he agrees that sometimes freedom may be misused and when it is misused can result in disaster.

\section{c. Pretension}

The last subtheme on the theme of spirituality was "pretension." This was explained by many of the respondents, generally the respondents justified that many Adventist students do not live a real life they just fake it. The spiritual life is full of pretense. Describing about this GGR2F commented, "Many young people have become pretenders, when they are at home they seem to be strong spiritually but when they reach here they try to hide but later on they reveal their real color."

This tells that the life of many students is occupied by pretensions. Another respondent FGR4F added, "The spiritual status for Adventist students at UOA is not good because many students are pretenders, and they normally try to hide the reality." All the above quotations affirmed that there is pretension going on 
among the Adventist students at the University of Arusha. Many scholars assume that pretense is just there in the society, so they have written more about how to overcome it rather than its presence in the community. Jamie [29] states that the hard truth is this: Overcoming pretense is hard work, painful work and an act of irrational vulnerability."

\section{Committed faith}

The second theme was "committed faith" out of it six subthemes emerged, tests and challenges, priority, upbringing, involvement, attending prayer and participation. These will be discussed the theme is discussed. The general statement from the respondents is that despite the spread of moral erosion amongst Adventist students many respondents agreed that, there is a possibility for Adventist students to have a committed faith if they surrender all to Jesus at all times. It is possible for the students to be stable spiritually. From the overall finding the researcher discovered that the University leadership and church can transform the current spiritual situation into good.

Adjusting some programs, taking seriously spiritual matters by emphasizing on spiritual life and enforcing rules things will be better. HGIR1 said, "Let us stick to time, time management is necessary for us to achieve and attract Adventist students." HGIR1 added, "Time management on worship should be a serious thing to consider; It bores when worship spends much time unnecessarily, this encourages dogging of some Adventist students." It seems that the current generation needs things which are done systematically and timely. Also FGR8M stated, "On Sabbath worship in the afternoon, let us have different programs like from 2:00-3:00; 3:00-4:00 to meet the spiritual needs have people." According to the above quotations, commitment to faith amongst Adventist students is shown by their participation in church or institutions' programs. This is affirmed by Nagy [30]. Adolescents' commitment to religious values and Seventh-day Adventist beliefs was significantly correlated with their service involvement.

\section{a. Tests and challenges}

Tests and challenges are used here in positive way; the respondents affirmed that the difficulties and challenges some Adventist students face in life make them to be closer to God and committed to faith. For example, HGIR2 stated that "Tests and challenges they face in life create commitment. Temptations and challenges help them to stand firm in faith. There are people when they do against God's standards they face challenges, this helps them to grow spiritually."

Here, challenges and trials are used as positive means for spiritual growth; HGIR3 added this, "Sometimes challenges and difficulties make us to be closer to God. We are in a church institution where we are not prohibited to worship we go to worship any time." The value of spiritual matters can only be seen when difficulties and challenges face the people who do not see faith and spiritual life as a precious and valuable opportunity in life. Commenting on the positive side of trials and suffering Korie [31] states, suffering results in all that is unstable being shaken out of your life. You cease to depend on people, programs, or material things as these all fail in your time of need. That is how God change bad things into profitable ones.

\section{b. Priority}

The subtheme of priority focuses on making God first in life for true and committed faith. When God is made the first priority in life spirituality becomes active in life. The overall finding is that, both church members and students agreed that the reason for some Adventist students becoming active at University of Arusha is the early parenting which was done by their parents when they were growing. It does not matter, whether spiritually or physically, people succeed when they prioritize things in life. Concerning those who succeed in life HGIR1 commented that, "They have made God their first priority, they read the word of God, spiritual books and they are awake spiritually because they pray."

That means God is on their ways of doing things they are not doing alone. Also they succeed because they put more emphasis on spiritual matters first as FGR2M stated, "Prioritize on spiritual activities and emphasizing on worship make them be closer to the source of power and success." This is in harmony with what Hagin [32] says, we see that day approachingthe coming of the Lord. We need one another. We need to grow up. We need to esteem earthly things lightly. We need to put God first. He talks about how we prioritize things in life as we see the second coming of Jesus Christ is approaching.

\section{c. Upbringing}

Committed faith does not come as an accident, it is prepared and planned. The upbringing subtheme emphasized on the importance of the early parenting of the parents toward their children. On this subtheme almost each participant agreed that our homes have a great contribution to the stability of faith of the children even when they are far away from their parents. HGIR2F said, "They have been brought up in the environment of independence from their childhood. This helps them to stand even when their parents are not there for them." Also GKR5F said, "Parents' upbringing of their children, being in small groups, Singing and having active Youth Department facilitate their commitment to faith." And HGIR3 added, "They have strong roots of the upbringing of their parents. When they come here they continue due to the well parenting style done by their parents." 
Commenting on the importance of early parenting Sanders and Alina [33], in the early years of life, parent-child interactions have an important impact on children's readiness to enter school. It seems that the readiness they are talking about is the ability to be stable and follow the values they were taught back home. Our study also indicated that those who were raised religiously were also protected from what are sometimes called the "big three" dangers of adolescence: depression, drug use, and risky behaviors. Tyler J. [34]. These ideas go hand in hand with what respondents suggested.

\section{d. Involvement}

The subtheme of involvement was proposed to be one of the reasons why some Adventist students remain stable spiritually when they join colleges and Universities. The overall finding in this particular subtheme testifies that Adventist students become active when they are involved in different programs of the church as well as of the University. When they are kept busy for God their attention will remain focused to God. GAR3F said this, "Involving in worship and church leadership, regular visitation involving students in gospel sharing programs and increasing more religious courses will help students to be active and committed." Adding to the same subtheme HGIR4 exhorted, "Using spiritual gifts, doing mission, arranged time for praying, reading and attending worships as well as good leadership will foster the commitment to faith of the Adventist students."

And finally GLR2M added, "Reading the scriptures, witnessing, more time in prayers, participation in church programs will keep students busy for eternity. According to the respondents' opinions, they seem to say that students are energetic; they need physical and spiritual activities in order to make them grow. Commenting on the importance of involvement Nagy [30] states, meanwhile results from this study support the hypothesis that there is a significant relationship between adolescents' commitment to religious values and Seventh-day Adventist beliefs, and their involvement in service.

\section{e. Attending Prayers}

Having the privilege of prayers on campus facilitates the commitment of some Adventist students to Jesus. The general finding testified that attending prayer meetings and worship in general was the reason for some Adventist students to be active and committed to spiritual matters. GGR4M agreed with that by testifying personally, "Strong programs of prayers, visitation and reading spiritual books help us to be committed to our precious faith as Adventists." It was strengthened by GBR1F who said, "The Presence of weeks of spiritual emphasis, also classes begin with God and end with Him. These strengthen us as we value it." From this perspective participation in prayers facilitates in increasing committed Adventist students.
Banister [35, 53] concurs with these ideas as he claims; the prayer meeting is a time to bear one another's burdens. His assertion suggests that every human being is likely in need of attending prayer meetings because all of us are overwhelmed by burdens and because of that we need to get a relief in prayers.

\section{f. Participation}

Lastly, participation was mentioned to be the reason for the commitment of some Adventist students to Jesus. The sum of the finding shows that participation in different programs of the church and University helps an individual grow. This helps the person to belong to the community. GHR6F stated that, "Participating in seminars on Sabbath afternoon and trying to uphold University Regulations though not seriously and morning and evening prayer sessions."

This was in agreement with GFR2F who exhorted, "Having morning and evening prayer sessions, attending worships, participating in several programs of evangelism and witnessing, having weeks of spiritual emphasis prayers in classes and several preaching in church have a great impact in the survival of Adventist students in faith." GIR1M had this to say, "Participating in spiritual programs is very important and singing. Students who are baptized are supposed to have membership in the University church where they are to facilitate their growth." On the same understanding Dan [36] has this to say, calling for commitment begins when you help people understand and pursue what they want. Shared commitment capitalizes on individual values. True commitment is the fruit of full participation in a shared vision which values each ones contribution.

\section{Inactive spirituality}

The third theme aimed to find out the reasons for the spiritual inactive of the Adventist students at the University of Arusha. Out of it three themes emerged, worldly influence, University leadership weakness and lack of involvement. The overall finding for this theme suggests that the major problem for the Adventist students at UOA to be inactive is the lack of leadership zeal to nurture them in spiritual matters. The leadership seems to forget their responsibilities as leaders of church institution; they operate like in secular University. HGIR1F mentioned familiarity as the reason for their inactive spiritually, she said, "Familiarity is the problem; I have been doing things since my childhood, nothing new.

They do not see value." They do not care at all whether God is watching and will hold them accountable one day. And FGR5M released his opinion, "They do not care about their spiritual life, familiarity and negligence cause their lukewarm. Most of them are born in Adventist family and because of that they do not value their faith, nothing new." All these are done because they are free to do whatever they feel to do 
since they are no longer under close care of their parents as HGIR1 added, "They become independent, they do not go to church by the force of their children, they reach at the University where they are no longer under the supervision of parents most of them fail to stand for themselves." This is supported by Stewart [37] who says, "Fully aware that involvement brings selfconfidence and commitment, this positive, opposite to this is what is called inactive state.

\section{a. Worldly influence}

Worldly influence contributes to the inactive situation among Adventist students. The overall finding suggests that the internal and external worldly influence enfeeble Adventist students badly. HGIR3 said, "The influence of worldly lifestyle, peer pressure, lack of private prayers, and lack of mission involvement laziness in reading scriptures. Adding to that HGIR4 described internal influence, "University Staff is rotten morally, the word of God is forgotten, and globalization and Worldly lifestyle are allowed on campus, no restrictions." The influence of peer groups has a negative impact to Adventist students too, GHR5M claimed, 'The influence of peer groups is dangerous to the spiritual life of students, they are influenced not to read scriptures and attending worships." These ideas are in harmony with the ideas of Armstrong [38] who says, often, when we are tempted to sin; we (like Solomon) become attracted to worldly influences.

\section{b. University Leadership Weakness}

In any successful organization, leadership plays a great role in such prosperity. The Adventist students' inactive spirituality is mentioned to be contributed by the leadership. The finding indicates that the members of focus group and interview both males and females, students and church members agreed that both church leadership and University leadership contribute much to the students' spiritual status because they are not guiding students according to the regulations. GFR5F said, "I have realized that when students join the University they change spiritually. This is because of the new environment, because they are so free in a University level; here is where leadership could enforce regulations." Human beings need guidance not freedom without boundary. GGR6M explained that, "I can say that, may be the reason behind the coldness and weakness is the leadership weakness towards implementing the regulations." And FGR2M added that, "Adventist students intermingle with dangerous groups, leadership could interfere and rescue them, for example, some are living in ghetto with non-Adventists, and this becomes a reason for them to be weak spiritually." It is in harmony with this article; ethical leaders model prevailing norms and standards of their organization and culture and enforce compliance with these standards among employees. This should be the way institutions run, things should be in order and guided properly.

\section{c. Lack of Involvement}

Another reason for spiritual inactive for Adventist students at the University of Arusha is described as lack of involvement. The general explanation for this situation is simply Many students are not involved in ministry and the life of the church in general. This affects them spiritually; instead of serving God they serve the devil by committing immoral behaviors. FGR4F said, "We do not have regular programs which involve them, we lack private prayers, church system also can contribute to this, we have large Sabbath school classes." FGR5F added, "Students are not seriously participating in Bible study, generally, they are not involved in church life and visitation is not done seriously."

They cannot afford to be idle and remain safe. And GKR2M commented, "When students are not witnessing, they are not participating in evangelism, what you expect? It is obvious they will automatically be weak spiritually." Adams [36] emphasizes and encourages the spirit of involving uninvolved in ministry as he says, we must be intentional as we seek out the uninvolved; being intentional means that involving the uninvolved becomes a ministry philosophy. This has a lot to teach about involving people in any organization or institution, it is either you chose to involve them or you lose them.

\section{Types of misconduct}

Several immoral behaviors were mentioned under the theme, 'types of misconduct' from this particular theme five subthemes came in, fornication/ adultery, cheating, alcoholism, inappropriate dressing and attending night clubs. The overall finding shows that the respondents agreed that there are various misconducts at the University of Arusha like fornication, adultery, attending night clubs/disco, taking alcohol, cohabitation, stealing and taking drugs. Almost every respondent when asked about the misconduct the Adventist students are accused to be involved in mentioned those. But fornication and adultery was often mentioned to indicate that it is a deadly problem to Adventist students at the University of Arusha. For example, FGR6F said this, "Different scandals are heard here and there from Adventist students even from students who take Theology, and they are accused of moral erosion."

Therefore from this finding, it seems that there is a problem of misconducts amongst the Adventist students at the University of Arusha. Awojobi [39] affirms the availability of misconducts in higher learning institutions, "Other renowned vices such as prostitution, cyber fraud, indecent dressing, drug abuse and cultism in Nigerian higher institutions still remain trendy... 


\section{a. Fornication /adultery}

If you grade the subthemes under the types of misconduct theme, fornication/ adultery takes the first grade. The general finding realizes that fornication and or adultery seem to be the highest misconduct Adventist students are accused of compared to other immoral behaviors. This is also exhorted by FGR4F, "The major problem we are facing here at the University of Arusha is fornication and adultery, and this is a serious thing."

FGR7M said, "I can mention one of misconducts, fornication or adultery is one of them, I have seen by my own eyes Adventist students being involved in fornication and adultery here at UoA." There is no doubt, adultery and or fornication is the deadly sin which is attacking many. Paul [40] supports the above understanding, We are living in sex crazing world that pornography has become home video, and fornication has become part of civilization. The devil is using this trap to capture people; we are living in such world where fornication seems to be civilization.

\section{b. Cheating}

Cheating in various semantic meanings happened to be among the mentioned subthemes in this study. The overall finding showed that there are unacceptable behaviors among Adventist students who join University of Arusha. Some are not faithful to what they are supposed to do as followers of Jesus. GCR4M stated, "Adventist students are cheating in examinations, committing adultery, taking alcohol. They are unfaithful; they rob and attend night clubs and musical Theaters." That is cheating in the sense that they do it knowing that it is bad and unacceptable before God.

On the same FGR6F added, "When I was in first year one Adventist guy conned me 10,000/= Tshs just to show me where I could be served as a new student. He took advantage of me being a new student." It seems that some of them have lost the sense of their identity as Adventists. On cheating Simmons [41] concurs as he says, "According to Rettinger and other researchers, students who cheat can still see themselves as principled people by rationalizing cheating for reasons they see as legitimate." This shows that cheating among students is there and some of them try to justify it as something acceptable.

\section{c. Alcoholism}

According to the study Some Adventist students are taking liquor, especially those whostay off campus. This has been discovered after an investigative study which aimed to know the reason and how it can be stopped. Testifying on that GBR5M said, "Alcoholism is a problem; I witnessed an Adventist student, pastor in training that was drinking alcohol in his room and eat lemon to quench the smell of alcohol." Adding to the same subtheme, GAR7M pressured, "Adventist students who stay off campus are in a risk of taking alcohol and other drugs. In fact some of them are drinking alcohol and smoking." All in all the above knowledge about University students taking alcohol is not strange as also Twersky [40] affirms, college students engage in alcohol consumption.

\section{d. Inappropriate dressing}

It is beyond doubt the appearance has a lot to teach to those who watch. The overall finding directs the University to practice the dressing code which is appropriate with the mission of the church. Our message should go hand in hand with how we appear before people. Half -naked dressing declares the level of conversion of the one dressing it. GER3M said that, "Those students, especially ladies who dress half- naked violate the regulation of dressing code." The three angels' message the church endeavor to do must help the messenger to appear with respect before people.

If the government has dressing code regulations what about religious organizations like the University of Arusha? FGR5M echoed, "How we dress matters here." In harmony with what was discussed above, Austin [42] has this to say; In terms of dressing children of God have a duty to present themselves worthy of their calling. Their dressing should be modest, appropriate and show them as stewards of God, who can manage God's resources well. This suggests that dressing code is necessary in our institutions to harmonize what we teach and how we appear before people.

\section{e. Attending Night Clubs}

Almost every week end comes with an invitation to attend night clubs and disco. The overall finding realized that attending night clubs and musical theaters were the normal things Adventist students were accused of. FGR4F said, "The hostellers are not safe for them; there are Adventist who go to Music Theatres. There are so much going on cars do take them to those places sometimes they come back in night or in the next day, these real things which are going on." Initially it was thought that girls who stay in University hostels are safer than those who stay off campus but this study has shown that it is not necessarily the case.

Testifying on the same subtheme HGIR1 said, "I was invited by my friend to go to Music Theater one night but I refused." This tells that there is a tendency of some Adventist students attending night clubs. On the common ground Hasson [43] states, "Diaz says people will always want to go out and dance with a group of friends, or go to a nightclub for a stag party or to experience the artist. This testifies that the presence of nightclubs is something going on in the society.

\section{Strategies to enhance commitment}

This theme is the heartbeat of the study because it led the researcher to find out the answer of the question, 'so what?' After all the investigations and 
discoveries, what should be done to help Adventist students be committed to God? This theme had six subthemes to curb the prevailing situation, Bible study, enforcing spiritual standards, being examples, involving students, follow up, conducting seminars. Therefore, as mentioned above the overall suggested strategies to combat the situation are like reading the Bible, enforcing spiritual standards, becoming examples, involving students, making follow ups, conducting creative seminars and worship programs as well as managing time. For example HGIR4 said that, "avoiding prolonging programs like Sabbath worship discourages the commitment to faith. Let us stick to time, time management is necessary for us to achieve and attract Adventist students."

People want systematic things; wastage of time in nonsense limits their full support and participation. Church and University leadership must work on those things to rescue the situation as FGR7M contributed, "Revisit the leadership of the University and put in position those who are willing to keep church values." And then HGIR4 raised a concern for hostellers, "The University should and must take care of those who stay in hostels by making available their basic needs." Temptations begins when they miss basic needs on campus and go outside for them, this increases risk. On this Depaola [44] affirms, many of us who grew up going to church, temple or Sunday school distanced ourselves because we found the experience boring. Something to ask is why was the experience boring? Among the major reasons may be irresponsible leadership.

\section{a. Bible study}

Due to the reason that this institution belongs to the Seventh Day Adventist Church, the first emerged subtheme was 'Bible study.' And the overall finding is that the tendencies of reading the Bible and other spiritual books will enable Adventist students to depend on God hence follow God's guidance. HGIR1 stated, "First of all is to read the word of God and know what God expects of them. Adding to the same HGIR2 said, "We should normally be selecting useful and difficult topics in the Bible for discussion." And finally, FGR8M suggested, "We are supposed to encourage our lecturers in Theology to write books in Swahili that will tackle topics which are the real need of people." Shiley [45] affirms that prayer is one of the greatest gifts and privileges we have as Christians because it is the means for us to connect with our creator. If the goal of the University of Arusha will be to transform students for eternity then Bible study will be mandatory.

\section{b. Enforcing spiritual standards}

Before and after the fall of man God was instructing Adam and Eve for them to follow his guidelines. So God is the God of order and instructions. Enforcing spiritual standards at the University of Arusha should not be seen as a strange thing. Generally, the finding suggested that the University and the church at large should make sure that they stand for the regulations based on their church policy and philosophy which aims to enable people who join our institutions to obtain salvation. HGIR2 said, "The University should lift up the spiritual standards of the University by enforcing the spiritual programs. This should be mandatory each student must attend worships." And GHR5F added, "Standing for University regulations, teaching our fundamental beliefs and students to have fellowship with University leaders should be mandatory." Covering the suggestions above Hagin [47] states, we are to take our stand on the Word of God and enforce our victory against a defeated foe. This statement encourages leaders to press on for Jesus without hesitation.

\section{c. Being good examples}

To be good examples wherever God's people are propels the commitment and supporting spirit of people. The overall finding on this subtheme is that leaders and workers are the ones violating moral life at the University of Arusha. Then it becomes difficult for the students to implement the regulations which are violated by their supervisors. GDR3F said, "Let leaders lead by examples, let them lead us to do what they emphasize." GLR3M added, "The University Workers should be good example on dressing code and hair plaiting, the church should encourage scripture reading and visit students where they stay to know their challenges." This is remarkable and recommendable. Toping up to the said above Arnold [48] summarizes, be an example of dedication and humility, and be a witness to the people for Jesus wherever you are.

\section{d. Involving students}

Most of the Adventist students attending the University of Arusha are young people; they are energetic, they need activities. Involving them becomes very important for the said reasons. The overall finding is that involving students in the activities of the church and university should be mandatory if at all the university and the church at large wants to save them. GIR4M commented, "We should fully involve youth in church mission programs," by doing that they will be working for their own growth also. And HGIR3 said that, "Involving University students in church activities include preparing attractive and acceptable programs that will capture their mind." The above ideas concur with what Laine [49] says; in any community personal experience and involvement are 'legitimate' and necessary factors to take into account when trying to help people grow.

\section{e. Follow up}

Working without follow up in administration and management declares failure. Being the fifth subtheme under the theme of strategies does not degrade its importance, it plays a great role in this study. In fact the general finding showed that this 
triggers the commitment of students instead of hatred as some seemed to suggest. GAR2M "We should be careful on how we make follow ups on life style of students like abstinence of Rasta, miniskirts earrings and plaiting hair, because they like it." This shows some compromising indicators, because how careful one will share the regulations? It should just be clear to the people, it is non-negotiable thing.

GFR5M said, "Follow up is a means of winning the confidence of young Adventist students because it shows the patriotism and seriousness of the leadership towards God's properties." FGR4F added, "Upholding University moral regulations by implementing follow ups will be beneficial for spiritual life; this includes visiting students to know their challenges." Expressing the need for change in leadership Arnold [50] mentions 'follow up' as the first thing among three mentioned, "I think over the years what I have learned is that follow-through, relationship building, and taking ownership for your work are more important.

\section{f. Conducting Seminars}

Apart from personal commitment, behavioral change includes knowledge of positive and negative side of it. Conducting seminars on relationship with God and human beings is necessary for behavior change of people. The accumulation of the ideas in this subtheme is that seminars and workshops on relationship should be conducted often at the University so that students may be grounded in Jesus. FGR4F said, "More seminars on spiritual matters to be done and the leadership be closer to Adventist students to know their challenges."

And FGR6M added, "Conduct seminars on how to be a moral Adventist University student; this will help students to know their identity." Explaining about the importance of seminars and workshops to spiritual growth Panigrahi [51] says, importance of seminars and workshops for students is often acknowledged as a prime concern. In comparison all the above findings have a great contribution in this study though the degree of its impact and urgency may differ from one to another.

\section{Recommendations to mitigate the Problem}

- There should be special planned programs which target to reach Adventist students in order to strengthen them spiritually.

- University leadership should review workers handbook to have a section which will address workers concerning their dressing codes and life conducts in general.

- The church is encouraged to continue with the programs which involve students for the purpose of keeping them busy for Jesus.

- The Adventist church at the University of Arusha should stand firm to the principles and teach them diligently to all who come to worship including students.

- The Dean of Students office in cooperation with the Chaplain's office should review and enforce their strategies on how they nurture Adventist students.

- Generally, the well-organized spiritual life of students should be the key factor for the existence of the University of Arusha.

- The chaplains' and Dean of students' offices are more responsible on implementing the regulations and policies for the development and effectiveness of students.

- Whoever will betray the plans and directives of the University and church at large let any necessary discipline be done to help such.

\section{REFERENCES}

1. Mentoring. (2020). Accessed 24 February 2020, https://www.encyclopedia.com/social-sciencesand-law/economics-business-and-labor/businessesand-occupations/mentoring

2. Langston, Scott, M. (2006). Blackwell Bible Commentaries: Exodus through the Centuries. Malden, MA: Blackwell, 170.

3. The Smyth, Z., \& Helwys. (2000). Bible Commentary Serie: A new Paradigm in Bible Commentaries Serious Scholarship in a MultiMedia Format. Georgia: Smyth \& Helwys Publishing, 239, 242.

4. Pitkanen, Pekka M. A. (2015). Apollos Old Testament Commentary: Joshua. Downers Grove, IL: InterVarsity, 140.

5. Dozeman, Thomas, B. (2015). The Anchor Yale Bible Joshua 1-12: A New Translation with Introduction and Commentary. New Haven \& London: Yale University Press, 257.

6. Chisholm, Jr, Robert, G. (2013). Teach the Text Commentary Series 1\&2 Samuel. Grand Rapids MI: Baker Books, 192.

7. Bodner, K. (2009). 1Samuel: A Narrative Commentary. Sheffield, TN: Sheffield Phoenix, 245.

8. Heaster, D. (2018). 2 Samuel: New European Christadelphian Commentary. Menai, Australia: Duncan Heaster, 145.

9. Hobbs, T. R. (1985). 13 Word Biblical Commentary: 2 Kings. Nashville, TN: Thomas Nelson, 25, 54, 72.

10. Gaebelein, Frank, E. ed. (1984). The Expositors' Bible Commentary: A Completely New Commentary Series on the Whole Bible. Grand Rapids, MI: Zondervan, 181, 364, 378, 419, 519, 599, 834, 889,

11. Maxwell, John, C. (2013). How to Influence People: Make a Difference in Your World. Nashville, TN: Thomas Nelson, 44.

12. Hagner, Donald, A. (1995). Word Biblical Commentary: Matthew 14-28. Nashville, TN: Thomas Nelson, 889. 
13. Keck, Leander, E. (1994). The New Interpreters Bible: A Commentary in Twelve Volumes, Nashville, TN: Abingdon Press, 503, 504.

14. Matthew, H. (2000). Commentary on the Whole Bible Volume V (Matthew to John) Grand Rapids, MI: Christian Classics Ethereal Library, 643.

15. Anderson, Neil T. (2003). Discipleship Counseling: The Complete Guide to Helping Others Walk in Freedom and Grow in Christ .Ventura, CA: Gospel Light, 21.

16. Barret, C. K. (1994). International Critical Commentary: On the Acts of the Apostles. Edinburgh: T\&T Clack, 627.

17. White, Ellen, G. (1911). The Acts of the Apostles. Mountain View, CA: Pacific Press, 203.1

18. Fee, Gordon, D. (1988). Understanding the Bible Commentary Series: 1\&2 Timothy, Titus. Grand Rapids, MI: Baker Books, 216.

19. Akin, Daniel, L. David Platt, and Tony Merida. (2013). Christ-Centered Exposition Commentary: 1 \& 2 Timothy and Titus. Nashville, TN: B\&H, 237, 284.

20. Brown, R. B. (1993). Meta-competence: a recipe for reframing the competence debate. Personnel Review.

21. Dictionary (2018). Research Methodology, $\begin{array}{llll}\text { accessed } & 18 & \text { February } & 2018\end{array}$ http://www.businessdictionary.com/definition/resea rch-methodology.html 5

22. Ndukwu, D. (2020). What is qualitative research? $\begin{array}{llll}\text { Accessed } & 17 & \text { September } & 2020\end{array}$ https://www.kyleads.com/blog/qualitative-research/

23. Saldaña, J. (2011). Fundamentals of Qualitative Research. Oxford: Oxford University Press, 154.

24. Rueda, M., R. Arnab, in Handbook of Statistics. (2016). Data Gathering, Analysis and Protection of Privacy Through Randomized Response Techniques: Qualitative and Quantitative Human Traits, accessed 1 October 2019, https://www.sciencedirect.com/topics/computerscience/data-collection-procedure

25. Benn, M. (2019). The private school system is 'morally rotten'. This could be the moment for its downfall accessed 11 October 2019. https://www.theguardian.com/education/2019/sep/ 10/private-school-system-morally-rotten-momentfor-downfall-melissa-benn

26. Conway, B. (2015). The Power-Destroying Danger of Familiarity, accessed 10 October 2019, https://benjaminconway.net/2015/12/08/the-powerdestroying-danger-of-familiarity/

27. Hybels, B., \& Mark, M. (1994). Becoming a Contagious Christian. Michigan: Grand Rapids, 200.

28. Taylor, D. (2010). The Naked Millionaire: The ultimate fast-track guide to wealth, freedom and fulfillment. Chichester, West Sussex UK: Capstone, 10.

29. Arpin-Ricci, J. (2013). Pretense: The Other Deadly Sin accessed 13 July 2019 https://churchleaders.com/outreach-

missions/outreach-missions-articles/165030-jamie-

arpin-ricci-pretense-other-deadly-sin.html

30. Nagy, A. C. (2014). Faith Commitments and Spiritual Influences as Correlates of Adolescents' Involvement in Service in the Valuegenesis Study, Michigan: Andrews University, 138.

31. Korie, M. (2019). Protection From Demonic Powers accessed 12 August 2019 https://schoolofapostles.blogspot.com/2013/11/prot ection-from-demonic powers.html

32. Hagin, K. E. (1996). Growing Up Spiritually. Kenneth Hagin Ministries: USA,47.

33. Sanders, M.R., \& Alina $\neg$ Morawska, Editors. (2018). Handbook of Parenting and Child Development across the Lifespan. The University of Queensland Brisbane, QLD Australia: Springer International Publishing AG, part of Springer, 19.

34. Vander Weele, T.J. (2019). Does a Religious Upbringing Promote Generosity or Not? An erroneous paper on religion and generosity is finally retracted accessed 12 Oct. 2019 https://www.psychologytoday.com/us/blog/humanflourishing/201909/does-religious upbringingpromote-generosity-or-not

35. Banister, G. (2019). The Importance of the Prayer Meeting accessed 9 September 2019, https://fpcurrent.com/importance-of-the-prayermeeting/

36. Adams, Chris. Involving the Uninvolved in Your Women's Ministry accessed 13 October 2019,https://womensministry.lifeway.com/2011/05/ 09/involving-the-uninvolved-in-your-womensministry/

37. Stewart, D. (2019). Michael. Inactivity accessed 13 September 2019 https://www.churchofjesuschrist.org/study/ensign/1 975/10/inactivity-helping-starts-with-knowingwhy?lang=eng

38. Armstrong, H.W. (2019). The Dangers of Desiring Worldly Influences accessed 12 October 2019, https://www.child-bible lessons.com/worldlyinfluences.html

39. Awojobi, K. (2019). Feature: Immoralities in higher institutions- Seen it all? Accessed 20 December 2019 https://newswings.com.ng/featureimmoralities-in-higher-institutions-seen-it-all/

40. Twersky, S. S. (2017). Coping Styles as Predictors of Alcohol Consumption with Undergraduate College Students Perceiving Stress (Philadelphia College Osteopathic Medicine: DigitalCommons 2017), 28.

41. Simmons, A. (2018). Why Students Cheat-and What to Do About It: A teacher seeks answers from researchers and psychologists accessed 15 October 2019 https://www.edutopia.org/article/whystudents-cheat-and-what-do-about-it

42. Austin, J. (2019). SDA's Dress Code!! Accessed 13 December

2019 
http://www.adventistonline.com/forum/topics/sdasdress-code

43. Hasson, B. (2015). Millennial Impact: The Evolution of Nightclubs accessed 10 December 2019

44. Depaola, K. (2016). How to Become More Spiritual accessed 11 December 2019 https://time.com/4341565/how-to-become-spiritual/

45. Shiley, K. (2019). 7 Reasons Why Prayer Is Important accessed 8 December 2019

46. https://www.prayerandpossibilities.com/importance -daily-prayer/

47. Hagin, K.E. (1994). The Triumphant Church: Dominion over all the powers of Darkness RHEMA Bible Church USA: Kenneth Hagin Ministries, 263.

48. Arnold, J. H. (2007). Discipleship: Living for Christ in a Daily Grind. Farmington PA: Plough, 183.

49. Laine, Marlene, De. (2000). Fieldwork, Participation and Practice: Ethics and Dilemmas in Qualitative Research. Bonhill London: SAGE, 4.

50. Arnold, P. (2009). Leadership in Practice: Patty Arnold Of St. John's Mercy Foundation accessed 14 January 2020

51. Panigrahi, S. (2020). Importance of Seminars and Workshops for Students in Higher Education $\begin{array}{llll}\text { accessed } & 13 & \text { January } & 2020\end{array}$ https://www.thehighereducationreview.com/news/i mportance-of-seminars-and workshops-forstudents-in-higher-education-nid-1261.html
52. Academy of Management Insights, Why Moral Leadership Matters accessed 14 October 2019https://journals.aom.org/doi/pdf/10.5465/anna ls.2016.0121.summary

53. Banister, G. (2019). The Importance of the Prayer Meeting accessed 9 September 2019, https://fpcurrent.com/importance-of-the-prayermeeting/

54. Keil, C.F., \&, Delitzsch, F. (2020). "Commentary on 1Kings 19:4." https://www.studylight.org/commentaries/kdo/1 kings-19.html. 1854-1889.

55. Sakenfeld, K.D. (1999). Ruth Interpretation: A Bible Commentary for Teaching and Preaching. Louisville, KE: John Knox Press, 12.

56. Trapp, J. (2020). "Commentary on Numbers 13:4". John Trapp Complete Commentary. https://www.studylight.org/commentaries/jtc/numb ers-13.html. 1865-1868.

57. The Registrar. (2018). University of Arusha, interview by the author, University of Arusha, 12 February 2018.

58. Wesley, J. (2020). "Commentary on Exodus 18:4" "John Wesley's Explanatory Notes on the Whole Bible".

https://www.studylight.org/commentaries/wen/exod us-18.html. 1765.

59. Wheadon, D. (2020). "Commentary on Numbers 13:4" "Wheaton's Commentary on the Bible". https://www.studylight.org/commentaries/whe/num bers-13.html. 1874-1909. 